\title{
A casual alien plant new to Mediterranean Europe: Ceiba speciosa (Malvaceae) in the suburban area of Palermo (NW Sicily, Italy)
}

\author{
Salvatore Pasta ${ }^{1}$, Tommaso La Mantia ${ }^{2}$ \& Emilio Badalamenti ${ }^{2}$ \\ ${ }^{1}$ Consiglio Nazionale delle Ricerche, Istituto di Bioscienze e BioRisorse, Corso Calatafimi 414 - 90129 Palermo, Italy \\ ${ }^{2}$ Dipartimento SAF, Viale delle Scienze Ed. 4, Ingr. H - 90128 Palermo, Italy \\ salvatore.pasta@ibbr.cnr.it; tommaso.lamantia@unipa.it; emilio.badalamenti@unipa.it
}

\begin{abstract}
Pasta, S., La Mantia, T. \& Badalamenti, E. 2014. A casual alien plant new to Mediterranean Europe: Ceiba speciosa (Malvaceae) in the suburban area of Palermo (NW Sicily, Italy). Anales Jard. Bot. Madrid 71(2): e010.

The abiotic and biotic characteristics of the first sites where floss silk tree behaves as a casual alien plant in the Mediterranean Europe are described. The species was probably first planted in botanical gardens of southern France few decades before mid XIX century. It was introduced in Palermo in 1896, a city which appears to match very well its climatic requirements. According to the available information on its biology and ecology in both its original and secondary range, the floss silk tree should not become an invasive alien plant in the Mediterranean. Nevertheless, several gaps need to be filled in order to increase our understanding of future trends of Ceiba speciosa in southern Europe, in particular, the eventual role of pollinators and seed dispersers outside the species' natural range.
\end{abstract}

Keywords: South America, neophyte, naturalization process, urban ecology, introduction history.

\section{INTRODUCTION}

The city of Palermo has been the place of first introduction and/or first naturalization of at least 30 of the 450 alien plants which may be considered as casual, naturalized or invasive (sensu Richardson et al., 2000) in Sicily (S. Pasta, personal data). This is the case of Nothoscordum borbonicum Kunth (Ross, 1889), Chasmanthe aetbiopica (L.) N.E. Br. (Fiori, 1923-1925), Cardiospermum grandiflorum Sw. (Di Martino \& Perrone, 1962; Schicchi, 1999), Tradescantia fluminensis Vell. (Orlando \& Grisafi, 1977), Ficus microcarpa L. (Schicchi, 1999) and Washingtonia filifera (Linden ex André) H. Wendl. ex de Bary (Raimondo \& Spadaro, 2006). Among others, Boerhavia coccinea Mill. (De Leo, 1967), Cenchrus setaceus (Forssk.) Morrone (Di Martino \& Perrone, 1962; Pasta \& al., 2010) and Melia azedarach L. (Badalamenti \& al., 2013) proved to be very invasive and occupied large areas thanks to the very effective long-distance dispersal vectors and paths, such as car wheels and motorways, respectively.

Ceiba speciosa (A. St.-Hil.) Ravenna, known worldwide with the basyonym Chorisia speciosa A. St.-Hil. and once assigned to the family Bombacaceae, is now included within Malvaceae (APG-III, 2009). With regard to European territory, according to DAISIE database (http://www.europealiens.org/speciesFactsheet.do? speciesId $=16630 \#$ ), it is naturalized on Madeira island. Consequently, the little nuclei recently found within the urban area of Palermo city represent the second case of casual naturalization (sensu Pyšek

\section{Resumen}

Pasta, S., La Mantia, T. \& Badalamenti, E. 2014. Una planta alóctona esporádica nueva para Europa mediterránea: Ceiba speciosa (Malvaceae) en áreas suburbanas de Palermo (NW Sicily, Italy). Anales Jard. Bot Madrid 71(2): e010.

Se describen las caracteristicas abióticas y bióticas de los primeros sitios del mediterráneo europeo donde el árbol palo borracho se encuentra creciendo como especie alóctona casual. Con respecto a la historia de su introducción, esta especie fue probablemente plantada en los jardines botánicos del sur de Francia unos pocos decenios antes de la mitad del siglo XIX. En 1896, sin embargo, fue introducida en Palermo, ciudad que parece satisfacer muy bien sus requerimientos climáticos. De acuerdo con la información disponible, tanto dentro como fuera de su área de distribución natural, el palo borracho no debería convertirse en planta invasora en el mediterráneo. Sin embargo, algunos vacíos de información deben ser completados antes de establecer su potencial invasor de una manera definitiva, particularmente, el posible papel de agentes polinizadores y dispersores fuera del área de distribución natural de la especie.

Palabras clave: América del Sur, neófita, proceso de naturalización, ecología urbana, historia de introducción.

et al., 2004) for the whole Europe and the first for the Mediterranean area. In order to evaluate its potential invasiveness, we carried out a deeper investigation on the environmental and demographic characteristics of the stands found in Palermo, the history of floss silk-tree introduction, and the species' biological and ecological traits.

\section{MATERIAL AND METHODS}

\section{Stand characteristics}

We collected the following basic data from each known stand: 1) GPS coordinates, 2) altitude (m a.s.l.), 3) occupied surface $\left(\mathrm{m}^{2}\right)$, 4) demographic structure of the population (i.e. number of individuals, estimated age range and percentage of each age category), 5) co-occurring species (if present) and 6) ecological meaning of species assemblage.

\section{Bibliographic research}

Special attention was paid to international, national and local botanical and horticultural texts with any reference to the basyonym Chorisia speciosa in order to reconstruct the history of its introduction in Europe, Italy and Sicily. Furthermore, we looked at the biology and ecology of floss silk tree within its natural range and in countries where it started to behave as a casual alien plant or a fully naturalised species. 


\section{RESULTS AND DISCUSSION}

\section{Abiotic and biotic characteristics of the known stands in Palermo}

A first colony with more than 40 seedlings and saplings of Ceiba speciosa was noticed by S. Pasta during late September 2006 in a $200 \mathrm{~m}^{2}$ green area between an abandoned industrial building and a parking site within the university domain; up to now 8 of them survived and reached a maximum height of $2.15 \mathrm{~m}$ (Fig. 1). Later on, during mid September 2013 two new nuclei have been discovered by T. La Mantia and E. Badalamenti. More in detail, a monophytic colony of about 20 (from few months to 2 years old) plants was observed growing within a gutter pipe at the "Policlinico" Public Hospital; the second one is located in the campus of Palermo University, where 10 seedlings and saplings, no more than 5 years old, grow scattered in different microenvironments such as sidewalks, irrigated gardens and even manholes (Fig. 2). In all the sites where the presence of Ceiba speciosa was detected, it forms small monophytic stands, or it is part of species-poor assemblages together with a few ruderal annual plants.

\section{Introduction history: facts and hypotheses}

Being a plant coming from Spanish and Portuguese colonies, the first seeds of Ceiba speciosa may well have been sent to botanical gardens in these countries, but no

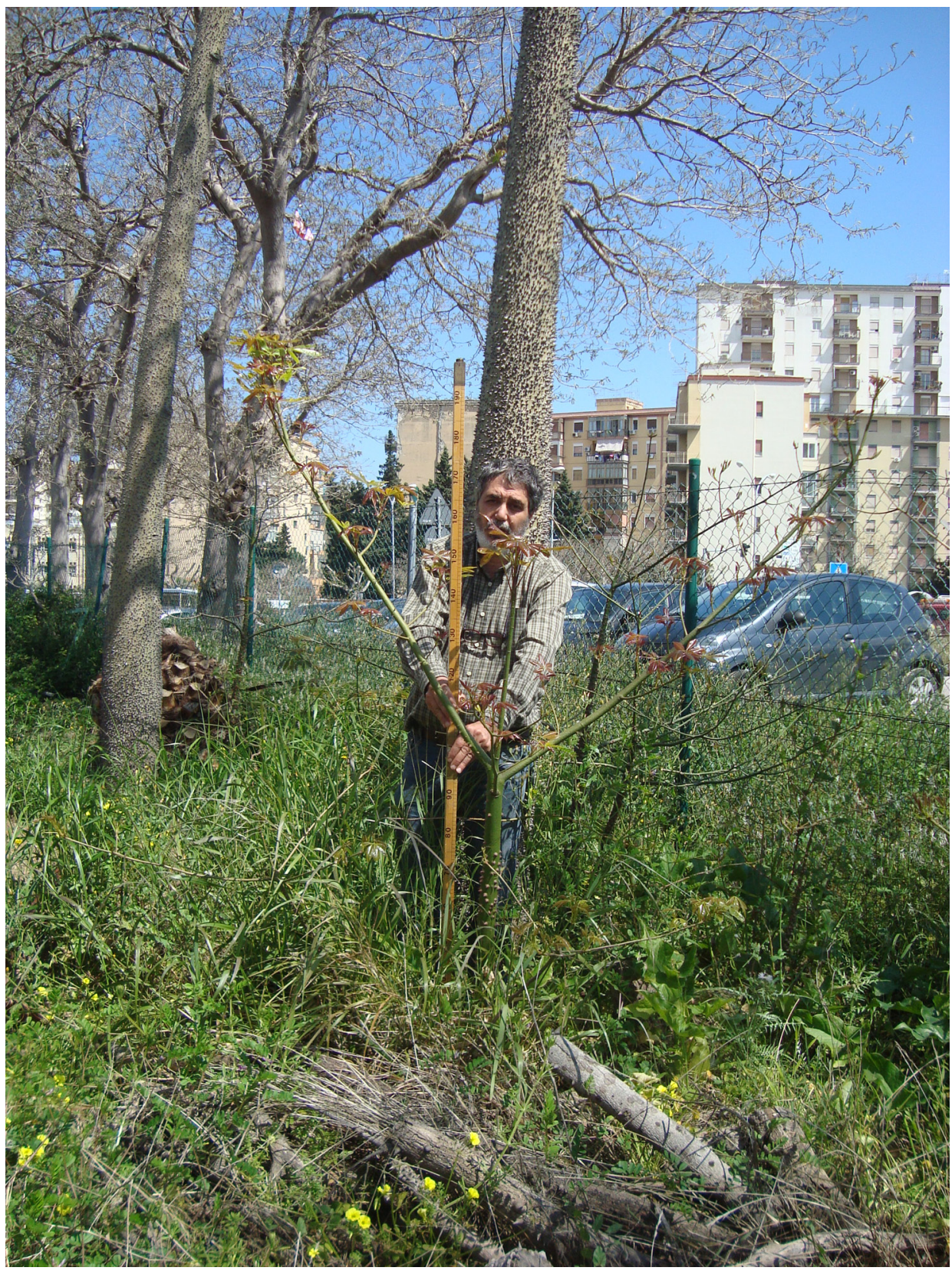

Fig. 1. Census and measurement of the extant young plants of Ceiba speciosa born near some adult individuals of the same species in a green area within the Palermo University domain (photo E. Badalamenti, April 2014). 


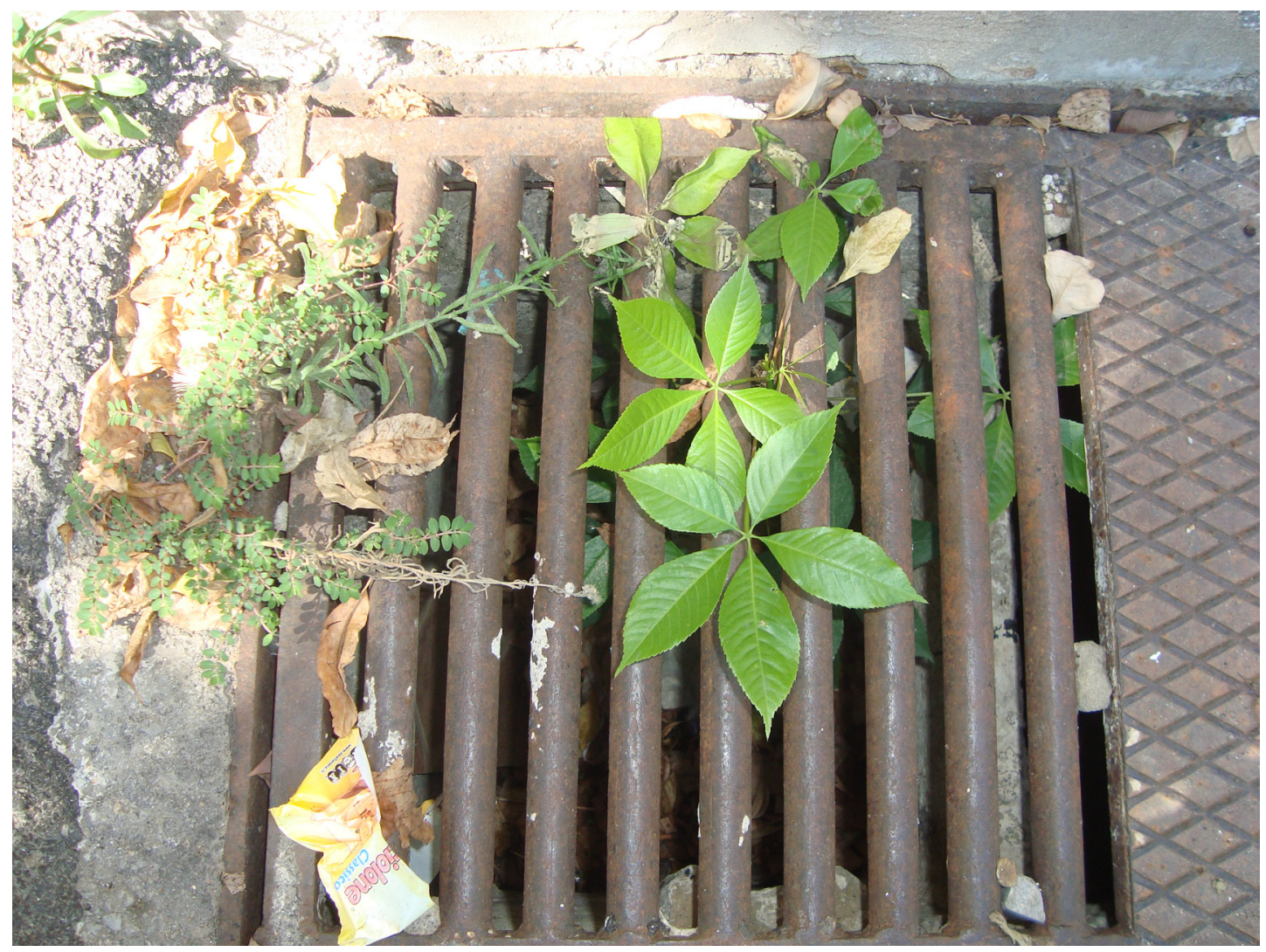

Fig. 2. A two years old sapling of Ceiba speciosa coming out from a manhole in the campus of Palermo University (photo E. Badalamenti, September 2013).

reliable references of these introductions have been found. Our efforts to trace the steps of its introduction in Europe were also hampered due to the frequent misapplication of the name Bombax ceiba L. in ancient books.

As far as we know, the first introduction of Ceiba speciosa may have happened on the French Mediterranean coast, and more precisely in Nice, where a large, maybe 60 years old and $10 \mathrm{~m}$ high tree was observed by Sauvaigo (1899). Moreover, the floss silk tree was already present in the Botanic Garden of Amsterdam around mid XIX century (Miquel \& de Groenewegen, 1857). There is also a report about its introduction to the botanical garden of Valencia soon after 1862 (Anonymous, 2006), where it could have been planted long before that year, given that during the visit of M. Maxime Cornu (professor at the Natural History Museum of Paris) to Valencia in 1887 he observed a huge $20 \mathrm{~m}$ tall plant growing there (Daveau, 1888). In 1864 a tree of Ceiba speciosa, very likely from propagation material sent from some French gardens, was cultivated in the Jardin d'Essai of Hamma near Algiers (Martins, 1866; Gerber, 1892). As concerns the Jardin des Plantes of Paris, Ceiba speciosa was not reported by Bernard \& al. (1842) but it was observed there in 1878 (Terracciano, 1894). In 1877 Julio Henriqus sent some seeds, from a plant cultivated in Coimbra Botanical Garden, to M.J. Daveau, gardener-inchief of the Polytechnic School of Lisbon (Daveau, 1888). Subsequently, the floss silk tree was introduced in several other European botanical gardens like Kew Gardens in England (Terracciano, 1894). Due to its high temperature requirements it was mostly kept in warm greenhouses. When planted outdoors, Ceiba speciosa survived and was able to develop only along the coastal cities of Portugal and Mediterranean Europe, where it started flowering by the end of XIX century, as in the Botanical Garden of Lisbon (Nardy, 1888), in several cities of S Spain (Bois, 1893-1899), at the Royal Palace of Caserta in S Italy (Terracciano, 1894), and in the Principality of Monaco in S France (Berger, 1913).

Being a noble born at Orléans, the French botanist and explorer Auguste François de Saint-Hilaire (1779-1853), who first discovered and described Chorisia speciosa (SaintHilaire, 1825), could have subsequently sent some seeds to somewhere in Europe, as for example to the gardeners of Bourbons (Spain and S Italy) and/or Orléans (Portugal, France, Sicily). As a fellow of the Academy of Sciences and Fine Arts of Palermo (Mortillaro, 1835), Saint-Hilaire certainly had some contacts with south Italian and Sicilian naturalists. As concerns Italian territory, Chorisia speciosa was already cultivated in the greenhouses of Caserta Royal Palace in 1872 (Della Valle, 2007). In a paper concerning the first trials to use the coat of the seeds for textile purposes, Terracciano (1894) states that Giovanni Gussone, a botanist working on behalf of the family of Bourbon as curator of the botanical garden of the royal palace, had the species in cultivation already around mid XIX century. Although no evidence is available on the origin of the plants cultivated at Caserta, Gussone may have collected some seeds from one of the botanical gardens he visited during his travel through 
Europe when accompanying the royal family in 1829 (Pasquale, 1872). For instance, in Paris Gussone met Adrien de Jussieu, companion of Saint-Hilaire during his exploration of Brazil and co-author of some of his scientific works (Saint-Hilaire \& al., 1827-1828).

As far as we know, Palermo represents the second site of introduction of Ceiba speciosa in Italy. Indeed, according to Lojacono-Pojero (1911), its seeds were presumably planted in a private garden of the city around 1896 by a "lady" coming from Brazil. Perhaps a member of the Orléans family played an important role as "seed disperser": in fact, after the end of the Empire of Brazil (1889), the last descendants of that dynasty left South America, and some of them occasionally spent some time in Palermo till 1931, when Isabela Orléans-Bragança married her cousin Henry of Orléans, count of Paris. However, the introduction of the floss silk tree is not reported in any of the books dedicated to the Palace of Orléans (Bazin, 1893; Di Matteo, 1961, 1983).

Whatever the origin of the seeds, their introduction in Palermo was fully successful, as suggested by the size of some of the trees, which were 18-22 m high and with a diameter of about $40 \mathrm{~cm}$ just fifteen years after sowing (Lojacono-Pojero, 1911). Once verified its resistance to drought and moderate cold, Ceiba speciosa was introduced in the Colonial Garden of Palermo (Catalano, 1916) together with two other silk-bearing tropical plants like Eriodendron anfractuosum DC., Ceiba pentandra (L.) Gaertn., the "true" silk-tree, and Bombax malabaricum DC. (= Bombax ceiba L.), in order to assess the quality and amount of available fibres - the so-called "false kapok" - which could be extracted from their fruits and transformed for textile purposes. Twenty years later the plants of Ceiba speciosa were so perfectly acclimatized that they were described as "superb" by Sorges (1934), who tested the technical properties of the oil extracted from its seeds in order to overcome the lack of fuel during the embargo suffered by Italy under the fascist regime (Bruno, 1952).

\section{Ecology}

Although widely introduced worldwide for ornamental purposes in public parks and botanical gardens, so far the floss silk tree seems no able to regenerate naturally outside its native range. This may be chiefly attributed to intrinsic biological constraints, mainly affecting the seedling stage. In fact, germination may occur either under light or shady conditions if adequate soil humidity is available, but subsequent seedlings growth is strictly limited to full-sun sites (de Souza \& Válio, 2001). Because burial may be tolerated for no more than 30 days, germination events appear also to be limited in time (Barbosa \& al., 2000), mostly showing a single peak (Ranal \& al., 2010). Seedlings development and establishment have proven to be particularly sensitive to light, microsite nutrient content as well as competition with co-occurring herbaceous species (de Souza \& Válio, 2001; Engel \& Parrotta, 2001); very high levels of seedlings mortality were recorded in the understory $(>97 \%)$, in medium to low soil fertility conditions $(>98 \%)$ and within competitive environments, suggesting that seedlings recruitment is strongly dependent on the presence of peculiar suitable microsites (de Souza \& Válio, 2001; Engel \& Parrotta, 2001).

\section{CONCLUDING REMARKS: WHAT IS THE FUTURE OF CEIBA SPECIOSA IN THE MEDITERRANEAN?}

\section{Reproductive behavior}

There still remain several gaps of knowledge in order to get a reliable model concerning the future trends of Ceiba speciosa in the Mediterranean region. Nevertheless, we stress the need to test the identity and the role of local pollinators and seed dispersers.

As pointed out by Gibbs \& al. (2004), floss silk trees seem to take significant advantage from cross-pollination, and natural populations were found to be primarily allogamous (Souza \& al., 2003). Although no information about this is available in Sicily up to now, in the absence of hummingbirds, the possible vectors worth investigating are weevils, butterflies, moths and bats (Fleming \& al., 2009).

Regarding seed dispersal, anemochory is not the only dispersal strategy of Ceiba speciosa. In fact, Garrett \& al. (1997) underlined the very strong dependence of the yellowchevroned parakeet (Brotogeris chiriri Vieillot, 1818) on the seeds of the floss silk tree, extensively cultivated within Los Angeles (California, U. S. A.). Thus, the increasing frequency of these exotic parrots in the green areas of Palermo may play an important role in the spread of this species, especially in suburban areas characterized by a complex patchwork of habitats with different degrees of naturalness and subject to different levels of disturbance.

\section{Climatic requirements}

Within its natural range (NE, SE and W Brazil, N Argentina, Paraguay, Bolivia and C-S Peru), Ceiba speciosa is a very common tree typical of mature (but not final) dynamic stages of drought-tolerant semi-deciduous forest (Kennard, 2002; Oliveira-Filho \& al., 2006) and the socalled cerrado, a tree savanna-like community (Ruggiero \& al., 2002; Rodal \& al., 2008), but it can thrive also along wet river valleys (Bianchini \& al., 2000; Gibbs \& Semir, 2003). This subtropical tree is perfectly adapted to stand a relatively dry season, which lasts from May to August. During these four months the monthly rainfall average values - always exceeding $100 \mathrm{~mm}$ during the rest of the year - drop down to $30-50 \mathrm{~mm}$ (Ruggiero \& al., 2002). The warm climate of S Mediterranean countries seems to fit well with floss silk tree requirements. In fact, old healthy individuals are rather common in several historical gardens of Cairo (Hamdy \& al., 2007) whilst the growth and the survival of the few plants of Barcelona (Spain) have been affected by rare frost events (Casasayas Fornell, 2003).

\section{Monitoring and control of Ceiba speciosa}

Although the first naturalization cases of Ceiba speciosa have been only recently recorded in several areas of the world, such as Hawaii, California, Florida and SE Australia (Hosking \& al., 2007), it seems unlikely that this species will become an invasive plant. For example, according to the Australian Weed Risk Assessment System (Gordon \& al., 2008), which evaluates the invasiveness of each introduced plant species through a multi-proxy approach (i.e.: taking into account several factors such as introduction pressure, 
weedy behavior, natural range, climate requirements, biology and ecology), Ceiba speciosa figures among the five taxa with lowest scores.

Nevertheless, we believe that for S Mediterranean, especially in Sicily, a periodic control of the extant populations and an accurate census of any new colony should be carried out.

\section{ACKNOWLEDGEMENTS}

We are grateful to Davide Fiorino and to the Accademia Nazionale dei Georgofili (Firenze) for their assistance during literature search. The suggestions and the original papers of many friends and colleagues helped us to reconstruct the history of introduction of Ceiba speciosa within European and Mediterranean countries; in this respect, special thanks are due to Stéphane Buord (Conservatoire Botanique National de Brest), Joachim Gratzfeld (Botanical Gardens Conservation International, London), Benito Valdés Castrillón (Universidad de Sevilla), Maria Dalila Espirito Santo (Jardim Botânico d'Ajuda, Lisboa), Carina Branco Azevedo Monteiro (Departamento Técnico, Jardim Botânico da Universidade de Coimbra), Emilio Laguna Lumbreras (Generalitat Valenciana, Sección de Protección de los Recursos Naturales) and Daniel Guillot Ortiz (Jardí Botànic de la Universitat de València). We are also indebted with Annalisa Santangelo (University of Naples) for the details on Gussone's travels and Caserta Royal Palace, and to Tiziana Turco (University of Palermo) for providing useful information on the history of the Orléans family in Palermo We are sincerely indebted to the associate editor and two anonymous referees, whose helpful suggestions allowed us to improve the paper.

\section{REFERENCES}

Angiosperm Phylogeny Group. 2009. An update of the Angiosperm Phylogeny Group classification for the orders and families of flowering plants: APG III. Botanical Journal of the Linnean Society 161: 105-121. http://dx.doi.org/10.1111/j.1095-8339.2009.00996.x

Anonymous. 2006. Decreto 134/2006, por el que se declara bien de interés cultural, con la categoría de jardín histórico, el Jardín Botánico de la Universidad de Valencia. BOE 275 (17/11/2006): 40536-40540.

Badalamenti, E., Cusimano, D., La Mantia, T. \& Pasta, S. 2013. The recent spread of the invasive woody alien plant Melia azedarach L. (Meliaceae), in Sicily. Il Naturalista siciliano, ser. 4, 37: 605-613.

Barbosa, J.M., Santos, Jr N.A. (dos) \& Pisciottano, W.A. 2000. Effect of burial and submersion on seed survival of native species used in riparian forestation. Revista Arvore 24:317-322.

Bazin, R. 1893. Sicile. Croquis italiens. Calmann Levy. Paris. 344 pp.

Berger, A. 1913. Chorisia speciosa St. Hil. Bullettino della Regia Società Toscana di Orticultura 38(10): 212-214.

Bernard, M.M.P., Couailhac, L., Gervais, P. \& Le Maout, E. 1842. Le Jardin des plantes: description complète, historique et pittoresque du Muséum d'histoire naturelle, de la ménagerie, des serres, des galeries de minéralogie et d'anatomie, et de la vallée suisse. Curmer editeur. Paris. 416 pp.

Bianchini, E., Medri, M.E., Pimenta, J.A., Giloni, P.C., Kolb, R.M. \& Correa, G.T. 2000. Anatomical alterations in plants of Chorisia speciosa A. ST.-HIL. submitted to flooding. Interciencia 25: 436-441.

Bois, D. 1893-1899. Dictionnaire d'borticulture illustré, Partie I. Paul Klincksieck Editeur. Paris. 640 pp.

Bruno, F. 1952. La Chorisia speciosa St. Hill. e la sua coltivazione in Sicilia. Lavori dell'Istituto Botanico e del Giardino Coloniale di Palermo 13: 1-19.

Casasayas Fornell, T. 2003. La flore ornamentale du nord-est de la Penisule ibérique. Bocconea 16(1): 73-79.

Catalano, G. 1916. Il Kapok. Origine, usi ed industria. Bollettino di Studi e Informazione del regio Giardino Coloniale di Palermo III(1-2): 3-27.

Daveau, M.J. 1888. Chorisia speciosa. Le Jardin 43: 270-271.

De Leo, A. 1967. Una nuova avventizia nel Palermitano: Boerhaavia repens Lin. ssp. viscosa (Choisy) Maire. Lavori dell'Istituto Botanico e del Giardino Coloniale di Palermo 22: 72-76.

De Souza, R.P. \& Válio, I.F.M. 2001. Seed size, seed germination, and seedling survival of Brazilian tropical tree species differing in successional status. Biotropica 33: 447-457. http://dx.doi.org/10.1111/j.1744-7429.2001. tb00198.x

Della Valle, M.F. 2007. Affinità elettive di un locus: il Giardino Inglese della reggia di Caserta. Quaderni Rivista Ricerche per la Progettazione del Paesaggio, Sezione Temi del Paesaggio "Orti botanici dell'800" 4: 126-149. http://www.unifi.it/drprogettazionepaesistica/

Di Martino, A. \& Perrone, C. 1962. Nuovo contributo alla flora arboricola di Palermo. Lavori dell'Istituto Botanico e del Giardino Coloniale di Palermo 18: 112-202.

Di Matteo, S. 1961. Gli Orléans a Palermo (Storia del Palazzo d'Aumale). S. F. Flaccovio Editore. Palermo. 171 pp.

Di Matteo, S. 1983. Il Palazzo d'Orléans. Linee d'Arte Giada. Palermo. $525 \mathrm{pp}$.

Engel, V.L. \& Parrotta, J.A. 2001. An evaluation of direct seeding for reforestation of degraded lands in central Sao Paulo State, Brazil. Forest Ecology and Management 152: 169-181. http://dx.doi.org/10.1016/ S0378-1127(00)00600-9

Fiori, A. 1923-1925. Nuova Flora Analitica d'Italia, contenente la descrizione delle piante vascolari indigene inselvatichite e largamente coltivate in Italia, vol. I. Tip. M. Ricci. Firenze. 944 pp.

Fleming, T.H., Geiselman, C. \& Kress, W.J. 2009. The evolution of bat pollination: a phylogenetic perspective. Annals of Botany 104: 1017-1043. http://dx.doi.org/10.1093/aob/mcp197

Garrett, K.L., Mabb, K.T., Collins, C.T. \& Kares, L.M. 1997. Food items of naturalized parrots in southern California. Western Birds 28: 196-201.

Gerber, M. 1892. Rapport de M. Gerber sur la visite faite par la Société au Jardin d'Essai du Hamma, près d'Alger. Bulletin de la Société Botanique de France 39: XCVIII-CI. http://dx.doi.org/10.1080/003 78941.1892.10828719

Gibbs, P.E. \& Semir, J. 2003. A taxonomic revision of the genus Ceiba Mill. (Bombacaceae). Anales del Jardín Botánico de Madrid 60: 259-300. http://dx.doi.org/10.3989/ajbm.2002.v60.i2.92

Gibbs, P.E., Bianchi, M.B. \& Taroda Ranga, N. 2004. Effects of self-, chase- and mixed self/cross-pollinations on pistil longevity and fruit set in Ceiba species (Bombacaceae) with late-acting self-incompatibility. Annals of Botany 94: 305-310. http://dx.doi.org/10.1093/aob/mch141

Gordon, D.R., Onderdonk, D.A., Fox, A.M., Stocker, R.K. \& Gantz, C. 2008. Predicting invasive plants in Florida using the Australian Weed Risk Assessment. Invasive Plant Science and Management 1: 178-195. http://dx.doi.org/10.1614/IPSM-07-037.1

Hamdy, R.S., Abd El-Ghani, M.M., Youssef, T.L. \& El-Sayed, M. 2007. The floristic composition of some historical botanical gardens in the metropolitan of Cairo, Egypt. African Journal of Agricultural Research 2: 610-648.

Hosking, J.R., Conn, B.J., Lepschi, B.J. \& Barker, C.H. 2007. Plant species first recognised as naturalized for New South Wales in 2002 and 2003, with additional comments on species recognised as naturalized in 20002001. Cunninghamia 10: 139-166.

Kennard, D.K. 2002. Secondary forest succession in a tropical dry forest: patterns of development across a 50-year chronosequence in lowland Bolivia. Journal of Tropical Ecology 18: 53-66. http://dx.doi. org/10.1017/S0266467402002031

Lojacono-Pojero, M. 1911. Sulla Chorisia speciosa S. Hil. a Palermo. Bollettino della Società Orticola del Mutuo Soccorso 9(1): 13-15.

Martins, C. 1866. Du Spitzberg au Sahara: étapes d'un naturaliste au Spitzberg, en Laponie, en Écosse, en Suisse, en France, en Italie, en Orient, en Égypte et en Algérie. J.-B. Baillière et Fils. Paris. 619 pp.

Miquel, F.A.G. \& Groenewegen, J.C. 1857. Catalogus horti botanici amstelodamensis. Apud M. Westerman \& filius. Amstelodami. 334 pp.

Mortillaro, V. (a cura di). 1835. Giornale di Scienze, Lettere e Arti per la Sicilia. Anno 13, vol. 51 (luglio-agosto-settembre), Tipografia del Giornale Letterario. Palermo. 708 pp.

Nardy, M. 1888. Le Jardin botanique et les jardins publics de Lisbonne. Journal de la Société Nationale d'Horticulture de France X: 469-474.

Oliveira-Filho, A.T., Jarenkow, J.A. \& Nogueira Rodal, M.J. 2006. Cap. 7. Floristic relationships of seasonally dry forests of Eastern South America based on tree species distribution patterns. In: Pennington, R.T., Lewis, G.P. \& Ratter, J.A. (eds.), Neotropical Savannas and Dry Forests: Diversity, Biogeography, and Conservation: 151-184. CRC Press, Boca Raton, FL.

Orlando, A. \& Grisafi, F. 1977. Appunti per la flora esotica d'Italia. Informatore Botanico Italiano 9(2): 113-114.

Pasquale, G.A. 1872. Documenti biografici di Giovanni Gussone botanico napoletano tratti dalle sue opere e specialmente dal suo erbario. Atti dell'Accademia pontaniana X (1871-72): 1-55 (estr.).

Pasta, S., Badalamenti, E. \& La Mantia, T. 2010. Tempi e modi di un'invasione incontrastata: Pennisetum setaceum (Forssk.) Chiov. (Poaceae) in Sicilia. Il Naturalista siciliano, ser. 4, 34: 487-525.

Pyšek, P., Richardson, D.M., Rejmánek, M., Grady, L., Williamson, M. \& Kirschner, J. 2004. Alien plants in checklists and floras: towards better 
communication between taxonomists and ecologists. Taxon 53: 131-143. http://dx.doi.org/10.2307/4135498

Raimondo, F.M. \& Spadaro, V. 2006. Casi di spontaneizzazione in Sicilia di specie esotiche ornamentali. Il Naturalista siciliano, ser. 4, 30: 597-599.

Ranal, M.A., Santana, D.G. \& Schiavini, I. 2010. Are there germination pat terns for cerrado species? In: Del-Claro, K., Oliveira, P.S., Rico-Gray, V., Barbosa, A.A.A., Bonet, A., Scarno, F.R., Garzón, F.J.M., Sampaio, M.V., Morris, M.R., Ramirez, N., Marçal Júnior, O., Macedo, R.H.F., Marquis, R.J., Coelho, L., Martins, R.P., Rodrigues, S.C. \& Luttge, U. (eds.), Encyclopedia of life support systems. Tropical biology and conservation management, savannab ecosystems: 106-159. UNESCO/EOLSS, Oxford. http://www.eolss.net

Ravenna, P. 1998. On the identity, validity and actual displacement in Ceiba of several Chorisia species (Bombacaceae), and description of two new South American species. Onira 3(15): 42-51.

Richardson, D.M., Pyšek, P., Rejmánek, M., Barbour, M.G., Panetta, F.D. \& West, C.J. 2000. Naturalization and invasion of alien plants: concepts and definitions. Diversity and Distributions 6: 93-107. http://dx.doi. org/10.1046/j.1472-4642.2000.00083.x

Rodal, M.J.N., Barbosa, M.R.V. \& Thomas, W.W. 2008. Do the seasonal forests in northeastern Brazil represent a single floristic unit? Brazilian Journal of Biology 68: 467-475. http://dx.doi.org/10.1590/ S1519-69842008000300003

Ross, H. 1899. Beiträge zur Flora von Sicilien. I Teil. Erläuterungen und kritische Bemerkungen zum Herbarium Siculum. Centuria I. Bulletin de l'Herbier Boissier 7(1-4): 262-299.

Ruggiero, P.G.C., Batalha, M.A., Pivello, V.R. \& Meirelles, S.T. 2002. Soilvegetation relationships in cerrado (Brazilian savanna) and semideciduous forest, Southeastern Brazil. Plant Ecology 160: 1-16. http://dx.doi. org/10.1023/A:1015819219386

Saint-Hilaire (de), A.F. 1825. Flora Brasiliae meridionalis. Vol. 1. Apud A. Belin. Parisiis.

Saint-Hilaire (de), A.F., Jussieu (de), A. \& Cambessèdes, J. 1827-1828 Plantes usuelles des Brésiliens. tav. XLIII. Grimbert Libraire. Paris.

Sauvaigo, E. 1899. Flora mediterranea exotica. Énumération des plantes cultivées dans les jardins de la Provence et de la Ligurie, avec un tableau des collections botaniques les plus importantes de Marseille à Gênes. Typographie J. Ventre. Paris. 454 pp.

Schicchi, R. 1999. Spontaneizzazione di Ficus microcarpa L. (Moraceae) e Cardiospermum grandiflorum Sw. (Sapindaceae) in Sicilia. Il Naturalista siciliano, ser. 4, 23: 315-317.

Sorges, F. 1934. L'olio di Kapok estratto dai semi di produzione siciliana. Bollettino di Studi e Informazione del regio Giardino Coloniale di Palermo XIII: 37-43.

Souza, L., Kageyama, P.Y. E Sebbenn, A.M. 2003. Sistema de reprodução em população natural de Chorisia speciosa A. St.-Hil. (Bombacaceae). Revista Brasileira de Botanica 26: 113-121. http://dx.doi.org/10.1590/ S0100-84042003000100012

Terracciano, N. 1894. La Chorisia speciosa St. Hil. del Giardino Botanico della Real Casa in Caserta. Atti del regio Istituto d'Incoraggiamento di Napoli 7(14): 1-7.

Associate Editor: Ricarda Riin Received: 11-IV-2014 Accpeted: 26-XI-2014 